\title{
Social preferences for invasive plant management: A case Study from the interior Northwest of the United States
}

\author{
T. J. Venn *, M. J. Wibbenmeyer ", \\ C. A. Armatas ", T. S. Prather * \\ Submitted: 01.06.2016 \\ Accepted: 06.06.2016
}

\begin{abstract}
Improved understanding of the benefits of invasive species management is necessary to inform economically efficient invasive species management and policy. Motivated by this need in the Interior Northwest of the United States, a choice experiment was designed to estimate society's marginal willingness to pay (MWTP) to avoid damage costs of invasive plants. Five ecosystem services at risk were included in the experiment: wildlife habitat; stream water quality; working landscapes and traditional means of livelihood in rural communities; occurrences of rare and threatened plants; and outdoor recreation. Multinomial logit $(M N L)$ and latent class $(L C)$ models were fitted to the data. Results allow two important conclusions to be made. First, the MNL models revealed that residents have a statistically significant MWTP to improve management of invasive plants and protect all ecosystem services examined. The MWTP estimates are suitable for integration within bioeconomic models that support development of economically efficient invasive plant control strategies. Second, the LC models highlighted heterogeneity in preferences about which impacts of invasive plants management should address. This suggests it may be challenging to gain and maintain broad political support for invasive plant management without a suite of public awareness campaigns tailored to specific segments of the population.
\end{abstract}

Keywords: Choice experiment, Choice modeling, Ecosystem services, Invasive species, Latent class model, Ecological impacts.

JEL Classifications: Q26; Q57; Q58

\footnotetext{
*College of Forestry and Conservation, The University of Montana, 32 Campus Dr., Missoula MT, USA 59812. School of Business, University of the Sunshine Coast, 90 Sippy Downs Drive, Sippy Downs QLD 4556, Australia. Email : tvenn@usc.edu.au

"College of Forestry and Conservation, The University of Montana, 32 Campus Dr., Missoula MT, USA 59812. At the time of publication, Mr. Wibbenmeyer is a PhD student in the Department of Economics, University of California, Santa Barbara, 2127 North Hall, Santa Barbara, CA, 93106, USA. Email : mwibbenmeyer@umail.ucsb.edu

College of Forestry and Conservation, The University of Montana, 32 Campus Dr., Missoula MT, USA 59812 Email : Christopher.arm at as@umontana.edu

`Department of Plant, Soil and Entomological Sciences, University of Idaho, 875 Perimeter Drive, Moscow, ID, 83844, USA. Email : tprather@uidaho.edu
} 


\section{Introduction}

The detrimental effects of invasive species on social and ecological systems are well documented, spanning both public and private domains (Pimentel et al. 2005; Foxcroft et al. 2013).Specifically, economic and natural resource management research has shown that invasive species have caused negative impacts, often referred to as damage costs, including biodiversity loss (Rice 2005; Clavero et al. 2009), degraded recreational experiences (Eiswerth et al. 2005; Beville et al. 2012), decreased agricultural profitability (Dosdall et al. 2011; Liu et al. 2012), decline in real estate values (Horsch and Lewis 2009; Zhang and Boyle 2010) and losses in water quality and quantity (Strayer 2010; Crous et al. 2012). In addition, managing invasive species through prevention, eradication, or long-term control is costly. In 2013, the United States Departments of Agriculture, Commerce, Defense, Homeland Security, Interior, State, Transportation, and the Environmental Protection Agency spent nearly $\$ 1.74$ billion on prevention, early detection, rapid response, and control and management of invasive species (National Invasive Species Council 2014).

Consistent with the prevalent trend throughout the fields of conservation science and natural resource management, invasive species management is increasingly focused on holistic approaches where interconnected social and ecological systems are considered as one system (i.e. a social-ecological system (SES)) and investigated through unifying concepts such as bio-economic models (Barbier 2001; Carrasco et al. 2012), and ecosystem services (Wainger et al. 2008; Pejchar and Mooney 2009).This trend is underpinned by the understanding that addressing complex environmental problems within SESs result in tradeoffs. For example, in the context of invasive species management, controlling an invasive species may impede the recovery of an endangered species (Lampert et al. 2014). A holistic approach to invasive species management requires a thorough and nuanced understanding of how invasive species affect human welfare. Economic research on invasive species achieves, in part, the nuanced understanding that the United States Department of Agriculture (2007) asserted is critical to support decisions about which pests should be controlled, what types of management strategies should be employed, and where and when particular management strategies should be used.

While management or control costs are often observable and relatively easy to estimate (Epanchin-Niell and Hastings 2010), estimates of benefits (avoided damage costs) of invasive species management programs are much more difficult to obtain and often include preliminary attempts to get a 'number on the table' (McIntosh et al. 2009). Such estimates offer limited support for development of socio-economically efficient invasive species management strategies and policy.

There are three main reasons why the majority of economic literature on damage costs and avoided damage costs of invasive species has limited utility for guiding management and policy. First, many economic studies of invasive species have 
focused on estimating total damage costs at broad spatial scales (e.g. Turpie and Heydenrych 2000; Pimentel et al. 2005), which highlight the importance of the invasive species problem, but are not useful for informing decision-making at the margin. Policy-makers and managers need to know how marginal avoided damage costs compare with the marginal control costs of particular invasive species management programs in specific landscapes (de Lange and van Wilgen 2010; Robison et al. 2010; Peh et al. 2015).

Second, most published studies focus on market costs of invasive species for particular stakeholder groups (e.g. reduced agricultural profitability), although the magnitude of damage costs to non-market goods and services that benefit society at large are thought to account for substantially more than $50 \%$ of the total economic value of invasive species damage costs (Lovett 2000; Born et al. 2005; Pimentel et al. 2005; Kaiser 2006). In particular, there are a lack of studies that employ stated preference non-market valuation techniques to estimate avoided damage costs of invasive species in terms of both use (e.g. recreation) and non-use values (e.g. bequest and existence values) (Rolfe and Windle 2014). Of the limited number of stated preference studies performed, most focus on invasive aquatic plant species (Rolfe and Windle 2014). A better understanding of societal preferences for invasive species management is important for gaining political support for investment of taxpayer dollars in control, and for understanding mismatches between public wants and expert opinions regarding the desired outcomes of control (Othman et al. 2004; McIntosh et al. 2010; Garrod et al. 2012; Marbuah et al. 2014).

Third, most studies that have estimated market or non-market damage costs of invasive species have done so by estimating replacement costs or expenditure reductions (e.g. Hirsch and Leitch 1996; Eiswerth et al. 2005; Juliá et al. 2007), which ignore changes in consumer and producer surplus and therefore underestimate damage costs. Surplus measures, not replacement costs, are needed to inform a "consistent and rigorous baseline against which we can judge the net value of any given set of policy options" (McIntosh et al. 2009:156).

Our goal was to contribute to the limited literature estimating society's marginal willingness to pay (MWTP) to avoid damage costs from invasive species. The design of the choice experiment facilitated estimation of marginal changes in surplus arising from alternative levels of provision of use and non-use ecosystem services due to invasive species management. This case study is the first choice experiment to have focused on invasive plant management in the Interior Northwest of the United States of America. The MWTP estimates reported are suitable for inclusion in bio-economic models that support development of efficient invasive plant control strategies. In addition, the regional scale latent class model highlights heterogeneous social preferences for invasive species management, adding nuance to the understanding of who reaps benefits from invasive species management. 
The paper proceeds with a description of the case study area. Section three provides an overview of the design and implementation of the choice experiment. Section four explains the models used to estimate preferences for invasive plant management and section five presents the results. The sixth and seventh sections discuss the implications of the choice experiment for managers and policy-makers and provide concluding remarks, respectively.

\section{Study Area}

The study area spans about $42 \mathrm{M}$ ha in western Montana, eastern Oregon, and Idaho, as illustrated in Figure 1. Like much of the western United States, the study area is dominated by public land managed by state and federal agencies. Only about one-third of the study area is privately owned, with the majority of the remaining land managed by either the Bureau of Land Management (BLM, 21\%) or the United States Forest Service (USFS, 37\%). A large portion (607,000 ha) of the land labeled as State, County, and Other Federal in Figure 1, is under the jurisdiction of the Bureau of Indian Affairs. This land encompasses the sovereign nations of several Native American tribes, including the Confederated Salish and Kootenai Tribes, the Confederated Tribes of the Umatilla Indian Reservation, and the Nez Perce Tribe. The study area is largely rural, with a total population of nearly $2.3 \mathrm{M}$, only one city exceeding 100,000 people, and a population density of 4.6 persons per square kilometer as compared to the continental U.S. population density of 35.2 persons per square kilometer. Agriculture and outdoor tourism and recreation are examples of important industries in the study area that are reliant upon a healthy environment. 
Figure 1. Study area in the Interior Northwest of the United States



Note: The study area includes all of Idaho. The counties that comprise the Montana portion of the study area are: Beaverhead, Broadwater, Deer Lodge, Flathead, Gallatin, Granite, Jefferson, Lake, Lewis and Clark, Lincoln, Madison, Mineral, Missoula, Powell, Ravalli, Sanders, and Silver Bow. The counties that comprise the Oregon portion of the study area are: Baker, Grant, Harney, Malheur, Umatilla, Union, and Wallowa.

The study area is ecologically diverse, containing high mountainous areas, semiarid sagebrush grasslands with extreme seasonal variation in temperature, and large coniferous forests (Holechek et al. 1998). Within the study area, 135 invasive plant species are listed on state noxious weed lists. These species include invasive grasses like cheat grass (Bromustectorum), forbs like knapweeds (e.g. Centaureastoebe and Centaureasolstitialis), and shrubs such as tamarisk (Tamarix spp.) and Scotch broom (Cytisusscoparius). In part due to the diversity among invaders and in part due to the various landscapes they invade, invasive plants have diverse economic impacts across the study area, for example, on agricultural productivity and recreation expenditures. Additionally, the large swaths of public land in the study area protect wildlife habitat and water quality, but both are negatively affected by invasive plants. Taxpayer-funded invasive plant control costs amounted to between $\$ 11 \mathrm{M}$ and $\$ 15 \mathrm{M}$ per annum in each of the states of Idaho, Oregon, and Montana in 2008 and 2009 (Wibbenmeyer 2010). 


\section{Survey design and implementation}

A choice experiment survey was designed to collect information to support development of socio-economically efficient invasive plant management strategies for the Interior Northwest of the United States. The management of specific invasive plants, such as yellow star-thistle (Centaureasolstitialis) and rush skeletonweed (Chondrillajuncea), is important to natural resource managers in the study area. However, to make the survey more germane for the general public, the survey addressed the management of terrestrial invasive plant species generally to protect the provision of important ecosystem services. The survey asked respondents their willingness-to-pay for increases in annual taxes to achieve particular outcomes regarding provision of important ecosystem services in 10 years. A 10-year time horizon balanced concerns for realism with concerns that the time horizon be near enough that respondents could envision how proposed changes might affect them.

Selection of the attributes for the choice experiment was completed via focus groups held in Missoula, Montana, and Boise, Idaho, in October 2009. The focus groups were attended by experts in invasive plant management from a variety of organizations, including Native American tribes, conservation groups, recreation groups, and county, state, and federal government agencies. The focus group discussions were centered on identifying and defining the most important ecosystem services at risk from invasive plants, the study area and the payment mechanism. Based on recommendations from focus group participants, the final set of choice attributes included in the questionnaire were recreation, wildlife habitat, water quality, occurrences of rare and threatened plants, and rural communities. The full choice attribute definitions (as provided to respondents) and methods for estimating the status quo and alternative levels of achievement for each choice attribute were discussed and agreed to by focus group participants and are available in Wibbenmeyer (2010). Brief definitions and the achievement levels for each choice attribute are reported in Table 1, but short descriptions of some attributes are warranted here to aid interpretation of results. 
Table 1. Definitions and alternative levels of achievement for choice attributes

\begin{tabular}{|c|c|c|c|}
\hline Attribute & Description & $\begin{array}{c}\text { Status } \\
\text { quo } \\
\text { level }\end{array}$ & $\begin{array}{l}\text { Alternate } \\
\text { levels }\end{array}$ \\
\hline RECREATION & $\begin{array}{l}\text { The percent of your outdoor recreation } \\
\text { experiences that will be seriously impacted by } \\
\text { invasive weeds } 10 \text { years from now. }\end{array}$ & 15 & $5,10,30$ \\
\hline WILDLIFE & $\begin{array}{l}\text { The percent of wildlife habitat in your state that } \\
\text { will be protected from invasion by invasive } \\
\text { weeds in ten years. }\end{array}$ & 80 & $\begin{array}{c}65,75,88 \\
93\end{array}$ \\
\hline WATERQ & $\begin{array}{l}\text { The number of kilometers of perennial streams } \\
\text { and rivers, including very small streams, in your } \\
\text { state that are likely to be listed by the U.S. } \\
\text { Environmental Protection Agency (EPA) as } \\
\text { threatened or impaired by sediment due to } \\
\text { invasive weeds in } 10 \text { years } 1 \text {. }\end{array}$ & +380 & $\begin{array}{l}+670,0 \\
-160\end{array}$ \\
\hline PLANTS & $\begin{array}{l}\text { The number of occurrences of rare and threatened } \\
\text { plant species in your state that will be lost due to } \\
\text { invasive weeds in } 10 \text { years. }\end{array}$ & -20 & $-40,-15,0$ \\
\hline $\begin{array}{l}\text { RURAL } \\
\text { COMMUNITIES }\end{array}$ & $\begin{array}{l}\text { The number of jobs in agriculture in your state } \\
\text { that will be lost due to the spread of invasive } \\
\text { weeds over the next ten years. }\end{array}$ & -190 & $\begin{array}{l}-500,-280 \\
-130,0\end{array}$ \\
\hline COST & $\begin{array}{l}\text { How much your household will pay each year } \\
\text { over the next ten years in federal, state, and local } \\
\text { taxes to fund weed management in your state. }\end{array}$ & 20 & $\begin{array}{c}10,30,50 \\
100,220\end{array}$ \\
\hline
\end{tabular}

Note: 1 .The survey instrument received by respondents reported length of degraded stream in miles. For the purposes of publication, these have been adjusted to kilometers.

The recreation attribute was broadly defined because of the diverse range of effects that invasive plants can have on recreation activities, and the wide variety of outdoor recreation people participate in. Invasive plants have many impacts on water quality, including impacts on flow, temperature and sedimentation. Defining and quantifying an attribute that addressed each of these impacts explicitly was not possible, so it was determined by focus group participants that the water quality attribute would focus on sedimentation. The rural communities attribute entered the survey as a proxy for the desire to maintain rural working landscapes and traditional means of livelihood. The attribute regarding rare and threatened plant occurrences was an attempt to accommodate concerns about the impact of invasive plants on native plant diversity and abundance in a quantifiable metric understandable to the average respondent.

Given only one-third of the study area is private land, with the majority of the remaining two-thirds federally owned, the only believable payment vehicle to support large-scale invasive plant management in the study area was taxes that fund management by government agencies. The status quo cost per household was estimated from federal, state and county allocations of taxes to invasive plant management over the period 2008to2009 in the states within the study area 
(Wibbenmeyer 2010). Respondents were informed that county, state and federal taxes are fully committed. Hence, increases in invasive plant management costs associated with implementing alternative strategies in the study area would have to be funded by increases in their federal, state and county taxes.

Given the six attributes and their corresponding levels, there are 3456 possible combinations of the attributes, which would be infeasible to present to survey respondents. An orthogonal main-effects experimental design was developed in SAS (Statistical Analysis Software) with the macros developed by Kuhfeld (2005). An efficient design size with 80 alternatives had 2 non-status quo alternatives per choice set, five choice sets per respondent, and eight survey blocks. Each choice set also contained the status quo management alternative, so respondent always had a 'no change' option. An example choice set is provided in Figure 2. Each respondent was randomly assigned one of the blocks and asked to select their preferred alternative from each of the five choice sets they received. 
Figure 2. Choice set example

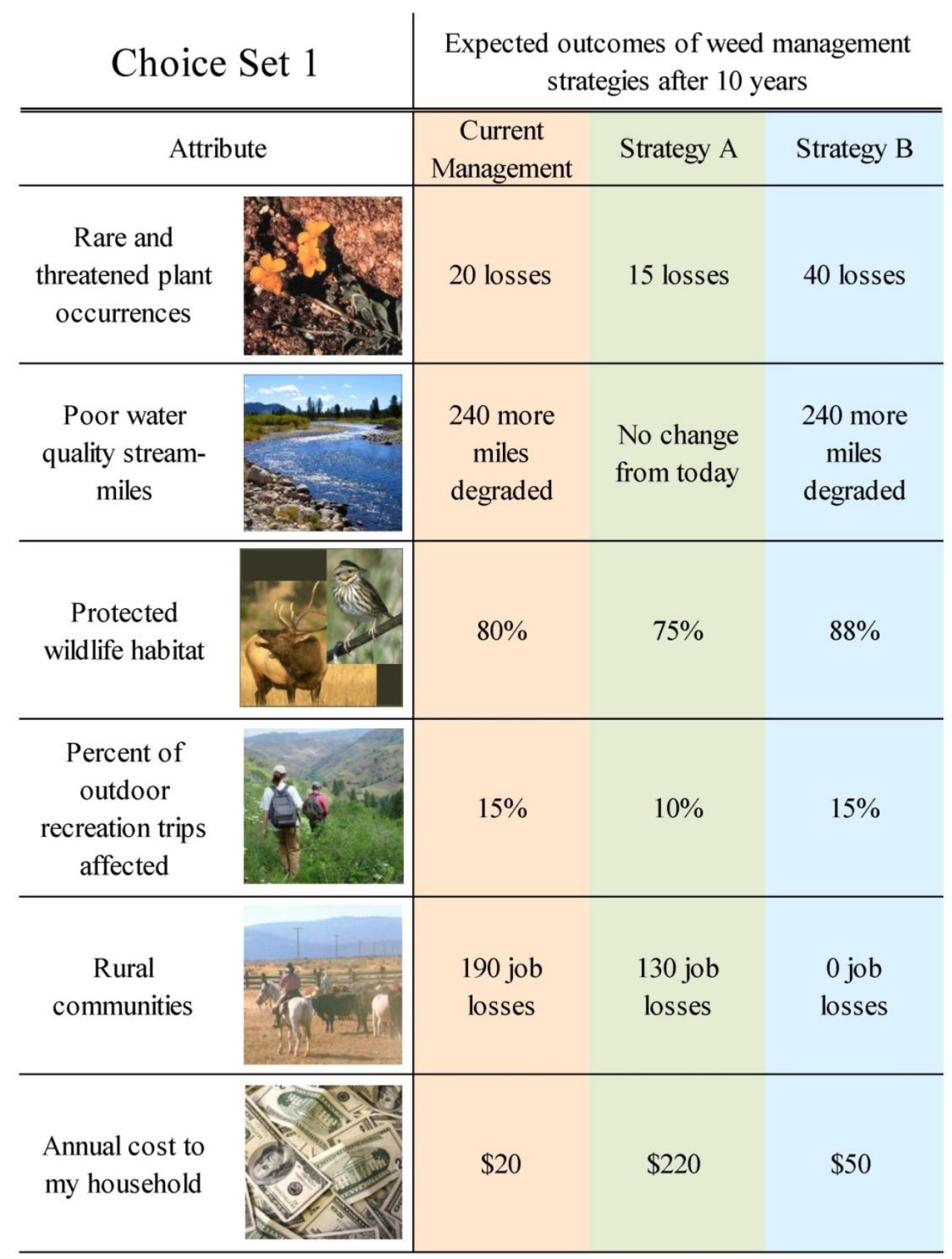

The survey was a 19-page color booklet with a large attention grabbing photo on its cover page. The first section included questions regarding the respondent's residence and experience with invasive plants. The second section provided 
information on invasive plants, including how they invade landscapes and the types of damage they cause, as well as specific information on five invasive plants that are problematic within the study area. The third section included the choice sets, and provided definitions of the attributes found in the choice sets. The final section requested information about the respondents (e.g. age, sex, occupation, income, and level of education) and their opinions about the survey.

The survey was reviewed by focus group participants and pre-tested at a shopping mall. Following some minor modifications, 1200 copies were mailed to a stratified random sample of residents in the study area to ensure an adequate number of responses were obtained from rural counties. A rural county was defined as acounty that did not have a city with a population greater than10,000. Following Dillman (2007), a pre-notice letter was sent to respondents, which described the survey that would be arriving in one week. The second contact was the survey instrument and included a cover letter that thanked respondents in advance for their participation, and a $\$ 2$ bill incentive payment. A postcard reminder was sent two weeks after the survey was mailed. Finally, a replacement survey with a different cover letter was sent to recipients whom had yet to return the survey two weeks after the postcard reminder.

\section{Theoretical models of preferences for plant management}

The choice experiment method was used to estimate demand for protection of attributes (ecosystem services) at risk from the spread of invasive plants, thus revealing social preferences for invasive plant management priorities. Choice experiments have been widely applied to natural resource management problems (e.g. Garber-Yonts et al. 2004; Han et al. 2008; Bateman et al. 2009; Boxall et al. 2009; O'Donnell et al. 2014). Choice experiments are based on two economic theories: Lancaster's characteristics theory of value (Lancaster 1966) and random utility theory (McFadden 1974). The choice experiment method is described in detail in Louviere et al. (2000) and Bennett and Blamey (2001) and brief notes describing our application follow.

The method posits that the utility function for respondent $n$, with a measured vector of socio-economic characteristics, $S$, and facing $j$ management alternatives that are described by outcomes for a vector of ecosystem services at risk, $X$, can be decomposed into observable and unobservable components

$$
U_{j n}=V\left(S_{n}, X_{j}\right)+\epsilon\left(S_{n}, X_{j}\right)
$$

where $V$ represents the observable elements of utility and $\varepsilon$ the stochastic unobservable elements of utility for the $j$-th alternative. Assuming that the respondent attempts to maximize utility from invasive plant management, the random utility model posits that the probability that respondent $n$ chooses alternative $i$ in set $J$ is 


$$
\operatorname{Pr}_{n}\left(i \mid J_{n}\right)=\operatorname{Pr}\left(U_{i n}>U_{j n}\right), \forall j \in J_{n}, i \neq j
$$

Combining equations (1) and (2), and rearranging terms gives

$$
\operatorname{Pr}_{n}\left(i \mid J_{n}\right)=\operatorname{Pr}\left(V\left(S_{n}, X_{i n}\right)+V\left(S_{n}, X_{j n}\right)>\epsilon\left(S_{n}, X_{i n}\right)+\epsilon\left(S_{n}, X_{j n}\right)\right), \forall j \in J_{n}, i \neq j
$$

To estimate equation (3), the stochastic components are typically assumed to be independently and identically distributed (iid) with a Gumbel or Weibull distribution. The multinomial logit (MNL) regression model is then used to estimate the probability of respondent $n$ choosing alternative $i$ as

$$
\operatorname{Pr}_{n}\left(i \mid J_{n}\right)=\frac{\exp \left(\mu V\left(S_{n}, X_{i n}\right)\right)}{\sum_{\mathrm{j}} \exp \left(\mu V\left(S_{n}, X_{j n}\right)\right)}, \forall j \in J_{n}, i \neq j
$$

where $\mu$ is a scale parameter inversely proportional to the variance of the error term and not separately identifiable. This parameter is usually assumed to equal one, implying constant error variance (Ben-Akiva and Lerman 1985).

Three MNL model specifications of the following functional form were fitted to the survey data with the statistical software package, STATA.

$$
\operatorname{Pr}_{n}\left(i \mid J_{n}\right)=\frac{\exp \left(\beta^{\prime} X_{i n}+\alpha Z_{i n}+\tau Q_{i n}+\gamma^{\prime} S_{n} X_{i n}\right)}{\sum_{j \in J} \exp \left(\beta^{\prime} X_{j n}+\alpha Z_{j n}+\tau Q_{j n}+\gamma^{\prime} S_{n} X_{j n}\right)}
$$

where $i, j, n, X$ and $S$ are as defined earlier; $\beta, \alpha$ and $\tau$ are coefficients estimated by the model; $Z$ is a scalar of the cost of particular invasive plant management strategies (cost levels are reported in Table 1); $Q$ is an alternative specific constant (ASC) that is unity for the status quo and zero for the other two alternatives in each choice set; and $S_{n} X_{\text {in }}$ is a matrix of interactions between the socio-demographic characteristics of respondents reported in Table 2 and the ecosystem services at risk reported in Table 1.

The first of the three MNL models was a basic model fit to the entire dataset without the interactions, $S_{n} X_{i n}$. Extensive preliminary analyses using standard $t$ tests of means of preferences for the choice attributes revealed that respondents from Idaho and eastern Oregon were statistically indistinguishable, but were statistically significantly different from western Montanan respondents. Therefore, invasive plant management preferences in the study area are best described by separate models for these two regions, and MNL models with covariates were fitted separately for (a) Idaho and eastern Oregon, and (b) western Montana. The covariates in these two models provide a way of accommodating preference heterogeneity and facilitate the weighting of sample preferences (i.e. account for sample biases) to represent the population as a whole.

The MNL models with covariates assume socio-demographic characteristics influence preferences independently. Latent class (LC) models provide a more nuanced picture of preference heterogeneity by allowing the sample to consist of distinct groups within which preferences are homogeneous. LC models are considered more appropriate for policy analysis in that they can provide 
policymakers and managers with an indication of the range of perspectives that exist in the population of interest. This is likely to be helpful in the development of campaigns to inform and perhaps persuade the public about the importance of action to address a particular problem.

Following Boxall and Adamowicz (2002), LC models assume the population consists of a discrete number of classes (C), and that preferences (i.e. probability of choosing alternative $j$ ) are homogeneous within class $c$, but may vary between classes. In this paper, class membership has been modelled as a logistic probability function of respondents' socio-economic characteristics, $S_{n}$, as follows

$\operatorname{Pr}_{n}\left(i \mid J_{n}\right)=\sum_{c=1}^{C}\left[\frac{\exp \left(\gamma_{c}^{\prime} S_{n}+\alpha_{c} Z_{n}+\tau_{c} Q_{n}\right)}{\sum_{c=1}^{C} \exp \left(\gamma_{c}^{\prime} S_{n}+\alpha_{c} Z_{n}+\tau_{c} Q_{n}\right)}\right]\left[\frac{\exp \left(\beta_{c}^{\prime} X_{i}+\alpha_{c} Z_{i}+\tau_{c} Q_{i}\right)}{\sum_{j \in J} \exp \left(\beta_{c}^{\prime} X_{j}+\alpha_{c} Z_{j}+\tau_{c} Q_{j}\right)}\right]$

where all variables are as defined earlier.

A disadvantage of the LC approach is that the number of population segments must be specified a priori or based on goodness-of-fit measures such as AIC (Andrews and Currim 2003; Vermunt and Magidson 2005). Separate LC models for Idaho and eastern Oregon, and western Montana were estimated using STATA. With no persuasive a priori hypothesis regarding the segmentation of preferences within the study area, LC models with 1 to 5 classes were fitted to data from both regions. The most appropriate number of classes was chosen on the basis of the goodnessof-fit measures BIC, AIC and AIC-3.

From the models represented by equations (5) and (6), average household MWTP for a one-unit improvement in protection of the $k$ th ecosystem service at risk $(X)$ can be estimated by equations (7) and (8), respectively

$$
\begin{aligned}
& -\left(\frac{\beta_{k}+\sum_{m=1}^{M} \gamma_{k m} R_{m}}{\alpha}\right) \\
& -\frac{\beta_{k}}{\alpha}
\end{aligned}
$$

where $R_{m}$ is the fraction of the population of the study area as a whole or region (i.e. Idaho and eastern Oregon or western Montana) that falls into each of the $m$ socio-demographic characteristic categories reported in Table2, and all other parameters are as defined above.

Following the method of Han et al. (2008), equation (7) produces an adjusted average household MWTP that corrects for the potential that respondents to the survey were not representative of the socio-demographics of the study area. One drawback of LC models is that, to predict class membership, variables within the class membership function must be observed jointly, making it challenging to scale sample average household MWTP to the population as a whole. For example, U.S. Census data applicable to the socio-demographic variables examined in this study are not available jointly. For this reason, it is appropriate that estimates of MWTP to support economically efficient resource allocation to manage invasive plants be 
taken from the MNL models with covariates, and the LC models are reported to support development of public information programs about invasive plants.

Aggregate MWTP for Idaho and eastern Oregon, and western Montana can be estimated by multiplying the average household MWTP estimates from the MNL models with covariates by the 633,728 and 222,312 occupied housing units in these regions, respectively (U.S. Census Bureau 2009). The scaling problem associated with $\mu$ in equation (4) is resolved when one attribute coefficient is divided by another, as in equations (7) and (8), since the scale parameter cancels out.

\section{Results}

The survey closed in June 2010 with 569 usable responses from 1109 delivered surveys (91 were returned by the post office as undeliverable), for an effective response rate of $51 \%$. As is common with postal surveys, respondents in this study were on average older, wealthier and better educated than the residents of the study area as a whole (Table 2). These results can largely be attributed to response bias; however, the stratification strategy adopted to obtain a sufficient number of responses from rural areas explains the high proportion of rural respondents in the sample. 
Table 2. Definitions for socio-economic covariates, and the proportion of respondents in the sample and in the population that fall into each of these demographic groups

\begin{tabular}{|c|c|c|c|c|}
\hline $\begin{array}{l}\text { Socio- } \\
\text { economic } \\
\text { variable }\end{array}$ & Definition & State or region & $\begin{array}{c}\text { Sample } \\
\text { mean } \\
(\%)\end{array}$ & $\begin{array}{c}\text { Population } \\
\text { mean }^{\mathrm{a}, \mathrm{b}} \\
(\%)\end{array}$ \\
\hline \multirow[t]{3}{*}{ WEALTHIER } & $=1$ for respondents with & Idaho & 11.0 & 13.7 \\
\hline & household income > & W. Montana & 9.3 & 5.8 \\
\hline & $\begin{array}{l}\$ 100,000 \text { per year; }=0 \\
\text { otherwise }\end{array}$ & E. Oregon & 9.2 & 5.1 \\
\hline \multirow{3}{*}{$\begin{array}{l}\text { MORE } \\
\text { EDUCATED }\end{array}$} & $=1$ for respondents with & Idaho & 45.0 & 29.7 \\
\hline & above a high school-level & W. Montana & 46.8 & 29.6 \\
\hline & education; $=0$ otherwise & E. Oregon & 46.0 & 20.7 \\
\hline \multirow[t]{3}{*}{ YOUNGER } & $=1$ for respondents younger & Idaho & 32.6 & 59.3 \\
\hline & than $50 ;=0$ otherwise & W. Montana & 36.6 & 55.2 \\
\hline & & E. Oregon & 30.3 & 52.1 \\
\hline \multirow[t]{3}{*}{ RURAL } & $=1$ for respondents self- & Idaho & 42.4 & 33.6 \\
\hline & identifying as living in rural & W. Montana & 44.3 & 48.8 \\
\hline & areas $;=0$ otherwise & E. Oregon & 49.3 & 42.5 \\
\hline
\end{tabular}

a. To be consistent with the survey request that respondents be a head of household 18 years of age or older, population means are calculated as percentages of households for household-specific variables (WEALTHIER, RURAL), and as percentages of all residents age 18 years or older for individual-specific variables (MORE EDUCATED, YOUNGER).

b. Sources: U.S. Census Bureau (2000), U.S. Census Bureau (2008), U.S. Census Bureau (2009).

Preliminary survey questions revealed that $84 \%$ of respondents recognize invasive plant management as an important socio-economic problem. Two-thirds of respondents indicated that their household is negatively affected by invasive plants on nearby public or private land. There is a high level of discontent with invasive species management; $44 \%$ of respondents asserted that state and federal governments are doing too little to control invasive plants. There is also a high level of support for the use of herbicides (89\%) and non-native insects or plant diseases $(68 \%)$ to control invasive plants.

The status quo management alternative was selected less than three times (out of five choice sets) by $65 \%$ of respondents, and $25 \%$ of respondents never selected the status quo. Only $10 \%$ of respondents always chose the status quo management option in each of the five choice sets presented to them. A standard $t$-test of means of socio-demographic (e.g. state of residence, income, age, education) and attitudinal characteristics (including aversion to additional taxes and distrust of government) of the respondents who always selected the status quo revealed no statistically significant differences relative to the rest of the sample. Their 
responses do suggest a preference for the status quo; however, given the experimental design, they are also evidence of inconsistent preferences with respect to the choice attributes. Following Adamowicz et al. (1998), these respondents were excluded from the analysis because they adopted a simple heurist decision rule and did not invest the time and effort necessary to carefully consider the management alternatives.

The final dataset for analysis included the preferences of 506 respondents for the 'without covariates' model, 95\% of whom completed all five choice sets in the survey. The 'with covariates' models and the latent class models for Idaho and eastern Oregon, and western Montana, had 336 and 170 respondents respectively. ${ }^{1}$

\subsection{Multinomial Logit Models}

Table 3 presents results for the MNL models. In the model without covariates, coefficients on all resources at risk are statistically significant at better than the $1 \%$ level. Higher levels of PLANTS, WATERQ, RURAL COMMUNITIES, RECREATION and COST correspond with worse outcomes, so the negative sign on the coefficients is expected. Higher levels of WILDLIFE represent an improved outcome, so the positive coefficient is expected.

The ASC coefficient is positive and statistically significant, indicating that respondents had a preference for the status quo regardless of the levels of COST and ecosystem services. There are complementary rational and psychological explanations of this common economic phenomenon, sometimes referred to as the status quo effect (SQE) or status quo bias (Thaler 1980; Adamowicz et al. 1998; Boxall et al. 2009; Meyerhoff and Liebe 2009; Carlsson 2010). Failing to accommodate the SQE in economic models may lead to exaggeration of individuals' responses to changing economic variables (Samuelson and Zeckhauser 1988).

\footnotetext{
${ }^{1}$ These numbers do not add to 506 because some respondents did not complete questions in the survey related to the socio-economic covariates used in the 'with covariates' model (e.g. household income) and were dropped from the analysis.
} 
Table 3. Multinomial logit regression results

\begin{tabular}{|c|c|c|c|c|c|c|}
\hline \multirow[t]{3}{*}{ Variable } & \multirow{2}{*}{\multicolumn{2}{|c|}{ Model without covariates }} & \multicolumn{4}{|c|}{ Models with covariates } \\
\hline & & & \multicolumn{2}{|c|}{ Idaho/eastern Oregon } & \multicolumn{2}{|c|}{ Western Montana } \\
\hline & $\begin{array}{c}\text { Coefficient } \\
\text { estimate }\end{array}$ & $p$-value & $\begin{array}{c}\text { Coefficient } \\
\text { estimate }\end{array}$ & $p$-value & $\begin{array}{c}\text { Coefficient } \\
\text { estimate }\end{array}$ & $p$-value \\
\hline PLANTS & $-0.0132 * * *$ & $<0.001$ & 0.0022 & 0.6840 & $-0.0177 * *$ & 0.0298 \\
\hline WATERQ & $-0.0031 * * *$ & $<0.001$ & $-0.0014 * * *$ & $<0.001$ & $-0.0018 * * *$ & $<0.001$ \\
\hline RURAL COMMUNITIES & $-0.0039 * * *$ & $<0.001$ & $-0.0035^{* * *}$ & $<0.001$ & $-0.0038^{* * *}$ & $<0.001$ \\
\hline WILDLIFE & $0.0253^{* * *}$ & $<0.001$ & 0.0062 & 0.4520 & 0.0006 & 0.9609 \\
\hline RECREATION & $-0.0177 * * *$ & $<0.001$ & 0.0046 & 0.5660 & $-0.0327 * *$ & 0.0104 \\
\hline ASC & $0.2519 * * *$ & $<0.001$ & $0.2285^{* * *}$ & 0.0010 & $0.3953^{* * *}$ & 0.0001 \\
\hline COST & $-0.0072 * * *$ & $<0.001$ & $-0.0078 * * *$ & $<0.001$ & $-0.0062 * * *$ & $<0.001$ \\
\hline WEALTHIER x PLANTS & & & -0.0146 & 0.1310 & -0.0202 & 0.2186 \\
\hline WEALTHIER x WATERQ & & & $-0.0007 *$ & 0.0710 & $-0.0016^{* * *}$ & 0.0093 \\
\hline $\begin{array}{l}\text { WEALTHIER x RURAL } \\
\text { COMMUNITIES }\end{array}$ & & & -0.0012 & 0.2320 & -0.0004 & 0.7656 \\
\hline WEALTHIER x WILDLIFE & & & 0.0205 & 0.1560 & 0.0007 & 0.9776 \\
\hline $\begin{array}{l}\text { WEALTHIER } x \\
\text { RECREATION }\end{array}$ & & & $-0.0252^{*}$ & 0.0960 & -0.0239 & 0.3149 \\
\hline $\begin{array}{l}\text { MORE EDUCATED } x \\
\text { PLANTS }\end{array}$ & & & -0.0051 & 0.3970 & $-0.0215^{* *}$ & 0.0100 \\
\hline $\begin{array}{l}\text { MORE EDUCATED x } \\
\text { WATERQ }\end{array}$ & & & $-0.0007 * * *$ & 0.0030 & $-0.0006^{*}$ & 0.0909 \\
\hline $\begin{array}{l}\text { MORE EDUCATED x } \\
\text { RURAL COMMUNITIES }\end{array}$ & & & 0.0001 & 0.9180 & 0.0001 & 0.8570 \\
\hline $\begin{array}{l}\text { MORE EDUCATED x } \\
\text { WILDLIFE }\end{array}$ & & & 0.0025 & 0.7940 & $0.0222^{*}$ & 0.0936 \\
\hline $\begin{array}{l}\text { MORE EDUCATED x } \\
\text { RECREATION }\end{array}$ & & & $-0.0192 * *$ & 0.0420 & -0.0164 & 0.2089 \\
\hline YOUNGER x PLANTS & & & -0.0075 & 0.2390 & 0.0019 & 0.8249 \\
\hline YOUNGER x WATERQ & & & -0.0003 & 0.1790 & 0.0004 & 0.2047 \\
\hline $\begin{array}{l}\text { YOUNGER x RURAL } \\
\text { COMMUNITIES }\end{array}$ & & & $-0.0013^{* *}$ & 0.0470 & $-0.0017 *$ & 0.0512 \\
\hline YOUNGER x WILDLIFE & & & $0.0382 * * *$ & $<0.001$ & 0.0155 & 0.2639 \\
\hline YOUNGER $\mathrm{x}$ & & & -0.0146 & 0.1400 & 0.0072 & 0.5998 \\
\hline RECREATION & & & & & & \\
\hline RURAL $x$ PLANTS & & & $-0.0169 * * *$ & 0.0050 & $0.0215^{* *}$ & 0.0113 \\
\hline RURAL x WATERQ & & & -0.0001 & 0.6400 & -0.0003 & 0.4319 \\
\hline RURAL x RURAL & & & 0.0003 & 0.6340 & -0.0002 & 0.8471 \\
\hline COMMUNITIES & & & & & & \\
\hline RURAL x WILDLIFE & & & 0.0112 & 0.2250 & $0.0243^{*}$ & 0.0806 \\
\hline RURAL x RECREATION & & & -0.0119 & 0.1980 & $0.0373^{* * *}$ & 0.0049 \\
\hline Number of observations & 7365 & & 4590 & & 2394 & \\
\hline Number of parameters & 7 & & 27 & & 27 & \\
\hline $\log \mathrm{L}$ & -2300.58 & & -1404.5 & & -706.3 & \\
\hline McFadden's R-squared & 0.1416 & & 0.1584 & & 0.1891 & \\
\hline $\begin{array}{l}\text { Adjusted McFadden's R- } \\
\text { squared }^{\mathrm{a}}\end{array}$ & 0.1390 & & 0.1422 & & 0.1582 & \\
\hline
\end{tabular}

Note: *,**,*** denotes statistical significance at the $10 \%, 5 \%$, and $1 \%$ level, respectively.

a. Adjusted McFadden's R-squared penalizes models with large numbers of parameters. 
In the two models with covariates, the coefficients on the ecosystem services at risk reflect change in probability of an invasive plant management strategy being selected for a base-case group of respondents who do not fall into any of the covariate categories. That is, they reflect the preferences of people under 50 years who live in households with incomes under $\$ 100,000$ per annum, have no more than a high school level of education, and live in an urban setting. Coefficients on socio-economic covariates represent the differences in preferences for the relevant socio-economic group relative to preferences of base case respondents.

Concerns about water quality and jobs within rural communities were important to respondents in Idaho and eastern Oregon. The level of PLANTS, WILDLIFE and RECREATION did not have a statistically significant effect on the probability of an invasive species management option being selected. Management preferences of high income and highly educated households were motivated by improved RECREATION outcomes. Younger respondents were the only socio-economic group with a statistically significant preference for management strategies that improved WATERQ and WILDLIFE, and rural households were the only socioeconomic group with a statistically significant preference for protection of PLANTS.

Base-case respondents in western Montana expressed statistically significant invasive plant management preferences for protection of PLANTS, RECREATION, WATERQ and RURAL COMMUNITIES. As in Idaho and eastern Oregon, higher income respondents and younger respondents in western Montana demonstrated greater concern than base case respondents for WATERQ and RURAL COMMUNITIES, respectively. Highly educated respondents in western Montana demonstrated greater preference for PLANTS, WATERQ, and WILDLIFE than base-case respondents. Rural respondents were less concerned than base case respondents about protection of PLANTS and RECREATION, but demonstrated greater preference for protection of WILDLIFE.

Table 4 reports average household MWTP for the models without and with covariates. Confidence intervals (95\% level) highlight that all average household MWTP estimates are statistically significantly different from zero. The estimates from the models with covariates were estimated with eq. (7) to be representative of the populations of the two regions in the study area. With the exception of WILDLIFE, residents of western Montana have higher average household MWTP for all ecosystem services at risk than residents from Idaho and eastern Oregon. 
Table 4. Average household MWTP to manage invasive plants in the study area.

\begin{tabular}{|c|c|c|c|c|}
\hline \multirow[b]{3}{*}{ Attribute } & \multirow[b]{3}{*}{ Marginal unit } & \multirow{2}{*}{$\begin{array}{l}\text { Model without } \\
\text { covariates }\end{array}$} & \multicolumn{2}{|c|}{ Models with covariates } \\
\hline & & & Idaho/eastern Oregon & Western Montana \\
\hline & & $\begin{array}{l}\text { Average household } \\
\text { MWTP (95\% } \\
\text { confidence interval) }\end{array}$ & $\begin{array}{l}\text { Average household } \\
\text { MWTP (95\% } \\
\text { confidence interval) }\end{array}$ & $\begin{array}{l}\text { Average household } \\
\text { MWTP }(95 \% \\
\text { confidence interval) }\end{array}$ \\
\hline PLANTS & 1 plant occurrence & $-\$ 1.8(-\$ 2.5,-\$ 1.2)$ & $-\$ 1.5(-\$ 2.7,-\$ 0.3)$ & $-\$ 2.2(-\$ 4.6,-\$ 0.1)$ \\
\hline WATERQ & 1 stream $\mathrm{km}$ & $-\$ 0.4(-\$ 0.5,-\$ 0.4)$ & $-\$ 0.2(-\$ 0.3,-\$ 0.2)$ & $-\$ 0.3 \quad(-\$ 0.5,-\$ 0.1)$ \\
\hline $\begin{array}{l}\text { RURAL } \\
\text { COMMUNITIES }\end{array}$ & 1 job & $-\$ 0.5(-\$ 0.6,-\$ 0.5)$ & $-\$ 0.5(-\$ 0.7,-\$ 0.4)$ & $-\$ 0.8 \quad(-\$ 1.2,-\$ 0.3)$ \\
\hline WILDLIFE & 1 percentage point & $\$ 3.5(\$ 2.5, \$ 4.5)$ & $\$ 4.6 \quad(\$ 2.7, \$ 6.5)$ & $(\$ 0.5, \$ 8.4)$ \\
\hline RECREATION & 1 percentage point & $-\$ 2.4(-\$ 3.5,-\$ 1.5)$ & $-\$ 2.2(-\$ 4.0,-\$ 0.4)$ & $-\$ 2.7(-\$ 5.8,-\$ 0.4)$ \\
\hline ASC & & $\begin{array}{r}\$ 35.9(\$ 18.3, \\
\$ 55.4)\end{array}$ & $\$ 29.4(\$ 2.6, \$ 56.1)$ & $\begin{array}{r}\$ 63.5(\$ 0.0, \\
\$ 127.0)\end{array}$ \\
\hline
\end{tabular}

The WTP calculation for the SQE is $\tau / \alpha$, resulting in a WTP of $\$ 29.40$ and $\$ 63.50$ annually for the next 10 years for status quo invasive plant management in Idaho and eastern Oregon, and western Montana, respectively. Ignoring the ASC is likely to overestimate WTP when evaluating alternative invasive plant management strategies. Subtracting the WTP for the status quo from the WTP for any management strategy that deviates from the status quo will provide a conservative interpretation of preferences and may represent a lower bound WTP (Garber-Yonts et al. 2004; Boxall et al. 2009).

Aggregate MWTP of residents in the study area to protect ecosystem services from invasive plants are reported in Table 5. Although the average household in western Montana generally has a higher MWTP, Idaho and eastern Oregon have a higher population and higher aggregate household MWTP. These estimates reveal, for example, that residents in Idaho and eastern Oregon, and western Montana are willing to pay $\$ 0.9 \mathrm{M}$ per year and $\$ 0.5 \mathrm{M}$ per year for 10 years, respectively, to avoid the loss of one occurrence of a rare or threatened plant.

Table 5. Aggregate MWTP to manage invasive plants in the study area

\begin{tabular}{|c|c|c|c|c|c|}
\hline \multirow[t]{2}{*}{ Attribute } & \multirow{2}{*}{$\begin{array}{l}10 \% \text { change from } \\
\text { status quo }\end{array}$} & \multicolumn{2}{|c|}{ Idaho/eastern Oregon } & \multicolumn{2}{|c|}{ Western Montana } \\
\hline & & $\begin{array}{l}\text { Aggregate } \\
\text { MWTP }(\$)\end{array}$ & $\begin{array}{l}\text { WTP for a } \\
10 \% \text { change } \\
\text { from the } \\
\text { status quo }(\$)\end{array}$ & $\begin{array}{l}\text { Aggregate } \\
\text { MWTP (\$) }\end{array}$ & $\begin{array}{l}\text { WTP for a } \\
10 \% \text { change } \\
\text { from the } \\
\text { status quo } \\
(\$)\end{array}$ \\
\hline PLANTS & 2 plant occurrences & $-\$ 926,690$ & $-\$ 1,853,381$ & $-\$ 490,170$ & $-\$ 980,340$ \\
\hline WATERQ & 38 stream $\mathrm{km}$ & $-\$ 155,940$ & $-\$ 5,988,112$ & $-\$ 70,237$ & $-\$ 2,697,115$ \\
\hline $\begin{array}{l}\text { RURAL } \\
\text { COMMUNITIES }\end{array}$ & 19 jobs & $-\$ 343,941$ & $-\$ 6,534,888$ & $-\$ 169,230$ & $-\$ 3,215,372$ \\
\hline WILDLIFE & 8 percentage points & $\$ 2,912,333$ & $\$ 23,298,665$ & $\$ 987,579$ & $\$ 7,900,631$ \\
\hline RECREATION & 1.5 percentage points & $-\$ 1,369,443$ & $-\$ 2,054,165$ & $-\$ 596,969$ & $-\$ 895,453$ \\
\hline ASC & & $\$ 18,607,027$ & & $\$ 14,110,018$ & \\
\hline
\end{tabular}


Note that since the units of measure for the levels of each choice attribute differ, it can be misleading to infer socially efficient protection priorities from the MWTP estimates in Tables 4 and 5. One way to interpret the results so as to reduce this effect is to estimate WTP for a specific percentage improvement, say $10 \%$, in levels of each attribute from the status quo. This is also reported in Table 5 and reveals that wildlife habitat protection had the highest aggregate household MWTP and the highest WTP to improve outcomes by $10 \%$ in both Idaho and eastern Oregon, and western Montana. Despite RURAL COMMUNITIES and WATERQ having the fourth and fifth highest aggregate household MWTP in both regions of the study area, they have the second and third highest WTP to improve outcomes by $10 \%$, suggesting society places a higher level of importance on these ecosystem services than revealed by casual interpretation the MWTP estimates.

\subsection{Latent Class Models}

Results from latent class analysis are presented in Table 6. A three-class model was best for Idaho and eastern Oregon, while a two-class model was best for western Montana. RURAL was not a statistically significant determinant of membership in any class, indicating that membership in alternative perspectives on invasive plant species management in the study area does not align with 'city' or 'country' residence.

In Idaho and eastern Oregon, class 1 (41\% of the sample) members are more likely to be older than 50 years, not highly educated, and have an annual household income less than $\$ 100,000$. They exhibit preferences similar to the base-case of the MNL model with covariates, having low MWTP for RURAL COMMUNITIES and WATERQ, while coefficients on the remaining ecosystem services are not of the expected signs. Members of this class can be characterized as valuing utilitarian ecosystem services, but not environmental values and recreation. 


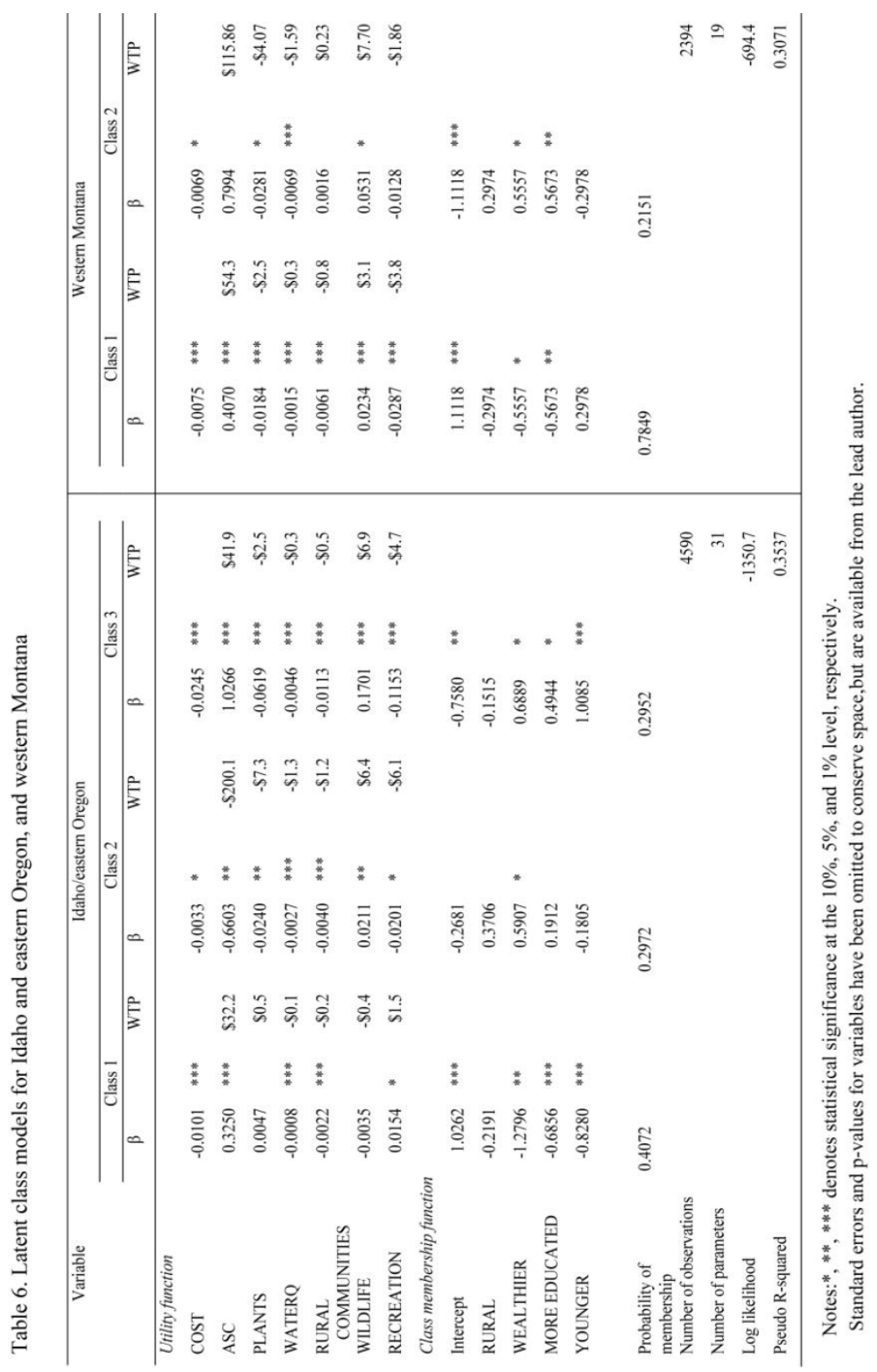

Class 2 (30\% of the sample) is not clearly defined by specific socio-economic traits, although high household income is statistically significant. Nevertheless, the utility function for class 2 is distinctive. They strongly favored non-status quo invasive plant management alternatives (negative ASC coefficient) irrespective of the cost and levels of ecosystem services, and also had the highest MWTP for all ecosystem services, except WILDLIFE. Members of class 2 can be described as highly concerned about the current trajectory of invasive plant management. 
Membership characteristics of class 3 (30\% of the sample) in Idaho and eastern Oregon are the opposite of class 1. Class 3 has substantially higher MWTP for all ecosystem services than class 1 , and has the highest MWTP for WILDLIFE. Class 3 members can be thought of as being concerned about the effects of invasive plants on all ecosystem services examined in this study, but still being somewhat averse to change, as indicated by a statistically significant ASC coefficient.

The LC model for western Montana revealed a large class, containing almost $80 \%$ of the sample, whose members are less likely to have high household incomes and high levels of educational attainment. Members of this class appreciate invasive plant management strategies that improve outcomes for all ecosystem services considered in this study.

In contrast, members of class 2 for western Montana have high MWTP for PLANTS, WATERQ and WILDLIFE, but statistically insignificant preferences for the use values RURAL COMMUNITIES and RECREATION. This class can be described as being strongly motivated to protect non-use values, and indifferent towards protection of the use values RURAL COMMUNITIES and RECREATION.

\section{Discussion}

Residents of the study area are willing to pay to reduce impacts of invasive plants on all ecosystem services considered in this study. While priority ordering of the attributes to be protected from invasive plants is challenging because of differences in units of marginal change, the results do suggest residents reserve their highest MWTP for protection of WILDLIFE, followed by RURAL COMMUNITIES and WATERQ, and then RECREATION and PLANTS.

Given socio-economic, ecological and sampling differences between non-market valuation studies, as well as differences in the way attributes are defined, quantified and valued, direct comparisons of WTP estimates with other studies may not be particularly meaningful. Nevertheless, comparisons are helpful as a check that estimates are in the right 'ball park', and to generate confidence in the numbers so as to encourage their use in support of policy and management.

The high MWTP to protect WILDLIFE reported in Tables 4 and 5 makes it apparent that the economic efficiency of invasive plant control treatments in the study area will be especially sensitive to their effectiveness at reducing invasion of wildlife habitat. Our MWTP estimate compares favorably with other studies in the western United States that have estimated WTP to protect the ecological integrity of wildlife habitat (e.g. Loomis and González-Cabán 1998; Garber-Yonts et al. 2004; Meldrum et al. 2013; O'Donnell et al. 2014). Our findings also compare favorably with other studies from the United States and internationally that have estimated MWTP to maintain or enhance populations of rare plants, and protect water quality and recreation opportunities from invasive plants and other threats 
(e.g. Zhang and Boyle 2010; Beville et al. 2012; Cerda and Losada 2013; O'Donnell et al. 2014; Yao et al. 2014).

We did not find a published study that used stated preference methods to value the avoidance of job losses. However, Armatas et al. (2014) revealed a prevalent perspective among residents in northwest Wyoming (about $300 \mathrm{~km}$ from our study area) that the preservation of rural livelihoods is important to people. In that study, respondents with no family connection to working farms identified several nonmarket benefits associated with preserving rural livelihoods, including preservation of the ranching culture and the working rural landscape against residential development. It is conceivable and legitimate that respondents to our survey were considering a diverse set of market and non-market benefits arising from the protection of RURAL COMMUNITIES when selecting their preferred invasive plant management strategies. Viewed in this light, it is appropriate that aggregate annual household MWTP is several times the market value of a rural job.

The aggregate household MWTP estimates can be used to evaluate the economic efficiency of invasive plant management programs implemented in addition to (not in replacement of) status quo management. For example, suppose an invasive plant control program is designed for western Montana that will improve outcomes for all ecosystem services evaluated in this study by $10 \%$ relative to the status quo. According to Table 5, the aggregate annual benefit of this program would be between a conservative lower bound of $\$ 1.5 \mathrm{M}$ and $\$ 15.7 \mathrm{M}^{2}$ (i.e. $\$ 7$ to $\$ 71$ per household per year), and the program would be economically efficient so long as projected annual costs of achieving the 10\% improvement are not greater than the benefits. It is noted that the MWTP estimates reported in this paper should be considered as a lower bound estimate of household MWTP to improve management of invasive plants, since many other benefits of invasive plant control were not valued.

In practice, evaluation of the economic performance of an invasive plant control program is more challenging than the previous paragraph might suggest. This is because the benefit of an additional unit of control is not simply the damages avoided today in the treated area, but the discounted future sum of damages avoided on the treated area, plus damages avoided in areas that would have been invaded by progeny of the invasive plants in the treated area. Integrated biological and economic (bioeconomic) models are necessary to simulate these benefits, and require: (a) a spatially and temporally explicit invasive plant presence and spread model; (b) a spatially and temporally explicit invasive plant control model that can simulate the cost and effectiveness (in containing the invasive species) of alternative treatments; (c) models that relate the level of invasive species on a landscape to impacts on provision of ecosystem services; and (d) estimates of MWTP to avoid impacts on provision of ecosystem services. Elements (a) and (b)

${ }^{2}$ The aggregate household MWTP for the status quo was deducted from $\$ 15.7 \mathrm{M}$ to provide the conservative lower bound interpretation of preferences. 
are increasingly available (e.g. Shafii et al. 2004; Tian et al. 2004; Frid et al. 2013; Aracena et al. 2014; Shafii et al. 2014; West et al. 2014). This study is an example of the growing body of research addressing element (d). The element in greatest need of research is (c). For example, how many hectares at what level of infestation are necessary for a particular invasive plant species to degrade water quality in a one kilometer stretch of stream?

While estimates of aggregate household MWTP from MNL models are useful, they do mask the heterogeneity in invasive species management preferences that can contribute to political challenges in putting policies into practice, particularly if management involves high costs or other inconveniences to households. In both regions (Idaho and eastern Oregon, and Montana) of the study area, the majority of respondents were members of classes that had statistically significant MWTP for invasive plant management that protected all ecosystem services examined. In Idaho and eastern Oregon, the utility function for members of class 2 (30\% of the sample) indicated a high MWTP for change away from status quo management of invasive plants, and high MWTP to protect all ecosystem services at risk. Nevertheless, members of class 1 , representing $41 \%$ of the sample in that region, were indifferent towards or had negative preference for invasive plant management targeted at protecting PLANTS, WILDLIFE and RECREATION. This suggests that invasive plants public education campaigns and management must include a strong focus on WATERQ and RURAL COMMUNITIES to ensure political acceptability in Idaho and eastern Oregon.

An alternative focus for public awareness campaigns and management appears warranted in western Montana. The ecosystem services positively valued by both classes were PLANTS, WATERQ and WILDLIFE. Class 1 members also expressed preferences for protecting RURAL COMMUNITIES and RECREATION; however, members of class 2 (22\% of the sample) were indifferent towards protecting these use-value centric ecosystem services. Public education campaigns and management in western Montana must accommodate non-use values to facilitate engagement with this class of higher income and higher educated households who have the highest MWTP for PLANTS, WATERQ and WILDLIFE in western Montana.

\section{Conclusion}

The dearth of marginal surplus estimates of the value society at large places on controlling invasive species to protect use and non-use ecosystem services means that invasive species management and policy is often developed with limited economic reasoning (Shogren et al. 2006). This can result in under-funded control programs and limited political support for control efforts that are funded due to mismatches between public wants and expert opinion about protection priorities. This case study represents an important contribution to the literature valuing the 
non-market benefits of invasive plant management and is the first choice experiment to have focused on societal preferences for invasive plant management in the Interior Northwest of the United States of America.

The results of this study allow two important conclusions to be made. First, the research demonstrates residents in the Interior Northwest of the USA place significant non-market values on ecosystem services threatened by invasive plants. These encompass both use and non-use values relating to protection of occurrences of rare and threatened plants, water quality, rural communities, wildlife habitat and recreation opportunities. Second, the results highlight the heterogeneity in preferences to reduce the impacts of invasive plants. The heterogeneity suggests that it may be challenging to gain and maintain broad political support for invasive plant management and may result in segmented appeals to media outlets utilized by each class of respondent. The results from the latent class analysis are useful for informing the design of public information and awareness campaigns, and management in the study area.

As respondents are unlikely to have been focused on particular invasive species, but rather on the type of damages that might be averted with appropriate management, the marginal willingness to pay (MWTP) estimates reported here may be suitable for benefit transfer to other issues that have similar potential impacts on the ecosystem services examined in this study. These estimates are also appropriate for integration within bioeconomic models to support development of economically efficient invasive plant control strategies. However, an important area for future research is to relate the level of invasive species infestation in space and time to changes in provision of particular ecosystem services. This will enable the estimation of change in quantity and quality of ecosystem services due to management, which must be multiplied by MWTP to predict welfare change.

\section{Acknowledgements}

This research was funded by USDA CSREES Integrated National Research Initiative Competitive Grants Program Number 2008-02991.We would like to thank Professor Douglas Dalenberg, Department of Economics, The University of Montana for econometric support, and the Bureau of Business and Economic Research, The University of Montana, for handling survey distribution and collection. We also greatly appreciate contributions from focus group participants. 


\section{References}

Adamowicz W, Boxall P, Williams M, Louviere J (1998): "Stated Preference Approaches for Measuring Passive Use Values: Choice Experiments and Contingent Valuation", American Journal of Agricultural Economics, 80(1),64-75.

Andrews RL, Currim IS (2003): "A Comparison of Segment Retention Criteria for Finite Mixture Logit Models", Journal of Marketing Research, 40,235-243.

Aracena P, Chung W, Jones G (2014): "Landscape-Level Simulation of Weed Treatments to Evaluate Treatment Plan Options", Invasive Plant Science \& Management, 7,278-290.

Armatas CA, Venn TJ, Watson AE (2014): "Applying Q-methodology to select and define attributes for non-market valuation: A case study from Northwest Wyoming, United States", Ecological Economics 107,447-456.

Barbier EB (2001): "A note on the economics of biological invasions "Ecological Economics,39,197-202.

Bateman IJ, Day BH, Jones AP, Jude S (2009): "Reducing gain-loss asymmetry: A virtual reality choice experiment valuing land use change", Journal of Environmental Economics and Management, 58,106-118.

Ben-Akiva M, Lerman SR (1985): Discrete Choice Analysis: Theory and Application to Travel Demand, MIT Press, Cambridge, MA.

Bennett J, Blamey R (2001): "The Choice Modelling Approach to Environmental Valuation", Edward Elgar Publishing Limited, Cheltenham, UK

Beville ST, Kerr GN, Hughey KFD (2012): "Valuing impacts of the invasive alga Didymosphenia geminata on recreational angling", Ecological Economics, $82,1-10$.

Born W, Rauschmayer F, Bräuer I (2005): "Economic evaluation of biological invasions-a survey", Ecological Economics, 55,321-336,

Boxall P, Adamowicz W (2002): "Understanding Heterogeneous Preferences in Random Utility Models: A Latent Class Approach", Environmental and Resource Economics 23,421-446.

Boxall P, Adamowicz WL, Moon A (2009): "Complexity in choice experiments: choice of the status quo alternative and implications for welfare measurement", The Australian Journal of Agricultural and Resource Economics 53,503-519.

Carlsson F (2010): "Design of Stated Preference Surveys: Is There More to Learn from Behavioral Economics?", Environmental and Resource Economics 46,167-177. 
Carrasco LR, Cook D, Baker R, MacLeod A, Knight JD, Mumford JD (2012): "Towards the integration of spread and economic impacts of biological invasions in a landscape of learning and imitating agents", Ecological Economics,76,95-103.

Cerda C, Losada T (2013): "Assessing the value of species: a case study on the willingness to pay for species protection in Chile", Environmental Monitoring \& Assessment, 185, 10479-10493.

Clavero M, Brotons L, Pons P, Sol D (2009): "Prominent role of invasive species in avian biodiversity loss", Biological Conservation, 142,2043-2049.

Crous C, Jacobs S, Esler K (2012): "Wood anatomical traits as a measure of plant responses to water availability: invasive Acacia mearnsii De Wild. compared with native tree species in fynbos riparian ecotones, South Africa", Trees, 26,1527-1536.

De Lange W, van Wilgen B (2010): "An economic assessment of the contribution of biological control to the management of invasive alien plants and to the protection of ecosystem services in South Africa", Biological Invasions, 12,4113-4124.

Dillman D (2007): Mail and Internet Surveys: The Tailored Design Method, John Wiley \& Sons, Hoboken, NJ.

Dosdall LM, Carcamo H, Olfert O, Meers S, Hartley S, Gavloski J (2011): "Insect invasions of agroecosystems in the western Canadian prairies: case histories, patterns, and implications for ecosystem function", Biological Invasions $13,1135-1149$.

Eiswerth ME, Darden TD, Johnson WS, Agapoff J, Harris TR (2005): "InputOutput Modeling, Outdoor Recreation, and the Economic Impacts of Weeds", Weed Science, 53,130-137.

Epanchin-Niell RS, Hastings A (2010): "Controlling established invaders: integrating economics and spread dynamics to determine optimal management", Ecology Letters, 13,528-541.

Foxcroft LC, Pysek P, Richardson DM, Pergl J, Hulme PE (2013): "The Bottom Line: Impacts of Alien Plant Invasions in Protected Areas",In: Foxcroft LC, Pysek P, Richardson DM, Genovesi P (eds). Plant Invasions in Protected Areas: Patterns, Problems and Challenges, 19-41

Frid L, Hanna D, Korb N, Bauer B, Bryan K, Martin B, Holzer B (2013): "Evaluating Alternative Weed Management Strategies for Three Montana Landscapes", Invasive Plant Science \& Management,6,48-59. 
Garber-Yonts B, Kerkvliet J, Johnson R (2004): "Public Values for Biodiversity Conservation Policies in the Oregon Coast Range", Forest Science, 50,589602.

Garrod G, Ruto E, Willis K, Powe N (2012):"Heterogeneity of preferences for the benefits of Environmental Stewardship: A latent-class approach", Ecological Economics, 76,104-111.

Han S-Y, Kwak S-J, Yoo S-H (2008): "Valuing environmental impacts of large dam construction in Korea: An application of choice experiments", Environmental Impact Assessment Review, 28,256-266.

Hirsch SA, Leitch JA (1996): The impact of knapweed on Montana's economy, Department of Agricultural Economics, Agricultural Experiment Station, Report No. 355, Fargo, ND.

Holechek JL, Pieper RD, Herbel CH (1998): Range Management: Principles and Practices, Prentice Hall, Englewood Cliffs, New Jersey.

Horsch EJ, Lewis DJ (2009): "The effects of aquatic invasive species on property values: Evidence from a quasi-experiment", Land Economics, 85,391-409.

Juliá R, Holland DW, Guenthner J (2007): "Assessing the economic impact of invasive species: The case of yellow starthistle (Centaurea solsitialis L.) in the rangelands of Idaho, USA", Journal of Environmental Management, 85,876-882.

Kaiser BA (2006): "On the garden path: an economic perspective on prevention and control policies for an invasive species",Choices, 21,139-142.

Kuhfeld WF (2005): Marketing Research Methods in SAS, SAS Institute, Inc, Cary, NC.

Lampert A, Hastings A, Grosholz ED, Jardine SL, Sanchirico JN (2014): "Optimal approaches for balancing invasive species eradication and endangered species management" Science, 344,1028-1031.

Lancaster KJ (1966): "A New Approach to Consumer Theory", Journal of Political Economy,74,132-157.

Liu N, Li Y, Zhang R (2012): "Invasion of Colorado potato beetle, Leptinotarsa decemlineata, in China: dispersal, occurrence, and economic impact."EntomologiaExperimentaliset Applicata,, 143,207-217.

Loomis JB, González-Cabán A (1998): "A willingness-to-pay function for protecting acres of spotted owl habitat from fire" Ecological Economics, 25,315-322.

Louviere JJ, Hensher DA, Swait JD (2000): Stated Choice Methods: Analysis and Applications, Cambridge University Press, Cambridge, UK. 
Lovett JC (2000): "Invasive species in tropical rain forests: the importance of existence values" In: Perrings $\mathrm{C}$, Williamson M, Dalmazzone $\mathrm{S}$ (eds). The Economics of Biological Invasions, Edward Elgar, Northampton, MA. pp $138-151$

Marbuah G, Gren I-M, McKie B (2014): "Economics of Harmful Invasive Species: A Review",Diversity (14242818) 6,500-523.

McFadden D (1974): "Conditional logit analysis of qualitative choice behavior" In: Zarembka P (ed). Frontiers in Econometrics, Academic Press, New York, NY. pp 105-142

McIntosh CR, Finnoff DC, Settle C, Shogren JF (2009): "Economic valuation and invasive species" In: Keller RP, Lewis MA, Lodge DM (eds). Bioeconomics of Invasive Species : Integrating Ecology, Economics, Policy, and Management, Oxford University Press, USA, Cary, NC, USA

McIntosh CR, Shogren JF, Finnoff DC (2010): "Invasive species and delaying the inevitable: Valuation evidence from a national survey" Ecological Economics, 69,632-640.

Meldrum JR, Champ PA, Bond CA (2013): "Heterogeneous nonmarket benefits of managing white pine bluster rust in high-elevation pine forests", Journal of Forest Economics,19,61-77.

Meyerhoff J, Liebe U (2009): "Status Quo Effect in Choice Experiments: Empirical Evidence on Attitudes and Choice Task Complexity", Land Economics, 85,515-528.

National Invasive Species Council (2014): "Invasive Species Interagency Crosscut Budget", The National Invasive Species Council Washington, D.C.

O’Donnell DT, Venn TJ, Calkin DE (2014): "Are wildfire management resources in the United States efficiently allocated to protect resources at risk? A case study from Montana",Economic Analysis and Policy, 44,318-332.

Othman J, Bennett J, Blamey R (2004): "Environmental values and resource management options: a choice modelling experience in Malaysia", Environment and Development Economics, 9,803-824.

Peh KSH, Balmford A, Birch JC, Brown C, Butchart SHM, Daley J, Dawson J, Gray G, Hughes FMR, Mendes S, Millett J, Stattersfield AJ, Thomas DHL, Walpole M, Bradbury RB (2015): "Potential impact of invasive alien species on ecosystem services provided by a tropical forested ecosystem: a case study from Montserrat", Biological Invasions, 17,461-475.

Pejchar L, Mooney HA (2009): "Invasive species, ecosystem services and human well-being", Trends in Ecology and Evolutions, 24,497-504. 
Pimentel D, Zuniga R, Morrison D (2005): "Update on the environmental and economic costs associated with alien-invasive species in the United States", Ecological Economics, 52,273-288.

Rice PM (2005): "Downy brome. In: Duncan CA, Clark JK (eds). Invasive Plants of Range and Wildlands and their Environmental, Economic, and SocietalImpacts. Weed Science Society of America, Lawrence, KS

Robison R, Schoenig S, Johnson DW, Brusati E, DiTomaso JM (2010): "California Invasive Plant Research Needs Assessment",Invasive Plant Science and Management,3,470-481.

Rolfe J, Windle J (2014): "Public preferences for controlling an invasive species in public and private spaces", Land Use Policy, 41,1-10.

Samuelson W, Zeckhauser R (1988): "Status quo bias in decision making", Journal of Risk and Uncertainty, 17-59.

Shafii B, Price WJ, Prather TS, Lass LW (2014): "Modeling dispersal of yellow starthistle in the canyon grasslands of Northern Idaho", International Journal of Plant Biology \& Research, 2,1011.

Shafii B, Price WJ, Prather TS, Lass LW, Thill DC (2004): "Using Landscape Characteristics as Prior Information for Bayesian Classification of Yellow Starthistle", Weed Science, 52,948-953.

Shogren JF, Finnoff D, McIntosh C, Settle C (2006): "Integration-valuation nexus in invasive species policy", Agricultural and Resource Economics Review, $35,11-20$.

Strayer DL (2010): "Alien species in fresh waters: ecological effects, interactions with other stressors, and prospects for the future",Freshwater Biology, $55,152-174$.

Thaler R (1980): "Toward a positive theory of consumer choice",Journal of Economic Behavior \& Organization, 1,39-60.

Tian F, Shafii B, Williams CJ, Prather TS, Price WJ, Lass LW (2004): "Prediction of yellow starthistle survival and movement over time and space", Proceedings of the Sixteenth Annual Kansas State Conference on Applied Statistics in Agriculture. Kansas State University Manhattan, KS. 74-96

Turpie J, Heydenrych B (2000): "Economic consequences of alien infestation of the Cape Floral Kingdom's Fynbos vegetation" In: Perrings C, Williamson $\mathrm{M}$, Dalmazzone S (eds). The Economics of Biological Invasions, Edward Elgar, Northampton, MA. 152-182

U.S. Census Bureau (2009): "2009, Annual Population Estimates", available from URL: http://factfinder.census.gov/ [accessed October 25, 2010]. 
United States Department of Agriculture (2007): "Program of Research on the Economics of Invasive Species Management, Fiscal 2003-2006 Activities". In: United States Department of Agriculture (ed), Washington, D.C

Vermunt JK, Magidson J (2005): "Latent Gold Choice 4.0: User's Guide", Statistical Innovations, Belmont, MA

Wainger LA, King DM, Mack RN, Price EW, Maslin T (2008):"Prioritizing invasive species management by optimizing production of ecosystem service benefits final report" In: United States. Department of Agriculture. Economic Research S (ed). U.S. Dept. of Agriculture, Economic Research Service, Washington, D.C.

West NM, Matlaga DP, Davis AS (2014): "Managing Spread from Rhizome Fragments is Key to Reducing Invasiveness in Miscanthus $\times$ giganteus", Invasive Plant Science \& Management, 7,517-525.

Wibbenmeyer, M.J. (2010): "Evaluation of Social Preferences for Invasive Weed Management in the Interior Pacific Northwest". M. S. Thesis, University of Montana.

Yao RT, Scarpa R, Turner JA, Barnard TD, Rose JM, Palma JHN, Harrison DR (2014): "Valuing biodiversity enhancement in New Zealand's planted forests: Socioeconomic and spatial determinants of willingness-topay",Ecological Economics, 98,90-101.

Zhang C, Boyle KJ (2010): "The effect of an aquatic invasive species (Eurasian watermilfoil) on lakefront property values", Ecological Economics, 70,394404. 